\title{
Drones under International Law
}

\author{
Rachel Alberstadt \\ University of Leiden (Advanced MA/LLM Public International Law (Peace, Justice, and Development)), Leiden, \\ The Netherlands \\ Email: r.a.alberstadt@umail.leidenuniv.nl
}

Received 7 July 2014; revised 10 August 2014; accepted 2 September 2014

Copyright (C) 2014 by author and Scientific Research Publishing Inc.

This work is licensed under the Creative Commons Attribution International License (CC BY).

http://creativecommons.org/licenses/by/4.0/

(c) (i) Open Access

\begin{abstract}
There is a notable absence of legal approaches to the discourse evaluating use of drones. Even when drones are discussed in a legal context, arguments assert that drones require a new legal regime to adapt to modern qualities and circumstances. In the alternative, this paper argues that drones compatibly fit into existing legal regimes, particularly international criminal law (ICL) and international humanitarian law (IHL) in accordance with general principles of international law. This paper argues that use of drones in armed conflict fits within existing laws governing use of force as the frameworks in use today. It demonstrates that ICL and IHL provide flexible guidelines appropriately suitable to particulars of drones, such as types and capabilities, but more importantly, they continue to provide legal governance applicable to drones as weapons. Legal uncertainty as to the use of drones is thus evaluated within the hypothetical exploration of drone usage culminating in a war crime before the International Criminal Court (ICC).
\end{abstract}

\section{Keywords}

International Law, Drones, International Criminal Law, International Criminal Court, International Humanitarian Law, Drone Warfare, International Crimes, War Crimes

\section{Introduction}

"In spite of the Terminator-like creepiness associated with machines seemingly making war on human beings, there is nothing legally unique about using unmanned drones as a weapon delivery platform that requires the creation of new or different laws to regulate their use" (Lewis, 2012).

The issue of drones presents an interesting debate, which partly argues that drones operate within a legal vacuum resulting from legal uncertainty as a modern development. To rebut this argument, this author posits that international criminal law (ICL) and international humanitarian law (IHL) both present legal regimes which continue to compatibly regulate the use of drones in armed conflict. This paper posits that drones are another tool operating within an existing legal framework which governs and restricts the use of force. It will focus its 
evaluative approach on scenarios where drones could result in breaches of ICL, culminating as war crimes within the meaning of Article 8 of the Rome Statute.

This paper will evaluate international laws which govern conflict in specific regards to rules applicable to the use of drones. The first chapter will evaluate factual elements of drones such as types, capabilities, and general uses. The second chapter will evaluate use of drones by examining how regulations of jus in bello (laws regulating the conduct of hostilities) apply to the use of drones in armed conflict. The final chapter will evaluate how the use of drones could be prosecuted as war crimes before the International Criminal Court (ICC).

\section{Drone Functions, Capabilities, and General Uses}

Drones are commonly referred to as unmanned aircraft systems (UAS), unmanned aerial vehicles (UAVs) or remotely piloted aircrafts (RPAs) - but for the purposes of this paper, the term drones will be used (Leander, 2013). For brevity purposes this paper will not extensively elaborate on the numerous varieties of drones. Instead, it will briefly point out that drones are primarily used for either un-armed purposes such as intelligence, reconnaissance and general surveillance or for armed purposes such as targeted killing operations (in this paper, "targeted killing" will be used in reference to lethal force to kill individuals that are outside of physical custody of the attacker) (Gill \& Fleck, 2010).

While this paper will only engage with evaluation of the use of drones during international warfare, it also notes that drones possess multiple functions, even outside the scope of warfare or intelligence gathering - such as aiding humanitarian causes. For instance, un-armed drones could be used to locate and bring aid to victims endangered from natural disasters. In another instance, drones could be used to drop humanitarian aid pallets to areas unable to be accessed by other means due to insufficient transportation or otherwise dangerous conditions prohibiting physical presence. These functions correlate with the variety and sizes of drones-from roughly the size of small aeroplanes to newer capabilities speculated to equal the size of a small insect (Knoops, 2012). In practice, smaller drones are unarmed and are primarily used for reconnaissance and target acquisition, while larger drones are equipped with missiles and used for higher altitude reconnaissance or to conduct aerial bombing campaigns (Vogel, 2011).

\subsection{Capabilities}

Drones are remotely piloted, unmanned aerial machines that vary in size and function (Leander, 2013). These factors reduce financial, material, and ultimately human costs of aerial warfare (Lewis, 2012). These aerial technologies have evolved with the advantage of protecting human resources, as it minimizes the need for human interference or physical troop deployment to the geographic areas in question. Drones also act as tools utilized specifically for their accuracy and are primarily employed for missions complicated by dangerous or difficult circumstances. Missile armed drones use surveillance scans to ensure the accuracy of the target within the parameters of identifying surrounding area and context of the operation. Lasers attached to the drone's camera allow for sniper-esque precision guided targeting (Schmitt, 2011). Additionally, the camera technology provides multiple visual feedback options, such as night vision, infrared, and other digital imagery at roughly real time speed (Schmitt, 2011).

In addition to laser guided precision, drones also possess extended hovering capabilities (Schmitt, 2011; Lewis, 2012). This means that when gathering intelligence about an intended target, the drone can hover over its target in order to collect updated information using high resolution imagery gathered roughly in real time (Schmitt, 2011). This data is transmitted to inform the pilot of ideal circumstances for which to launch the attack. These hovering or loitering capabilities present drones with abilities for 24/7 surveillance which means that the pilot can assess patterns of the target and the general area in order to determine factors for weapon engagement (Matthews \& McNab, 2011).

Furthermore, drones can carry missiles which vary in size and power (Alston, 2010) in order to be directly proportionate to the drone's function itself. By this it is meant that missiles carried by armed drones can be smaller as to minimize impact, just as the size of the drone itself is meant for accuracy and agility. This illustrates part of the confusion with the perception of drone results. There is a misperception that launched drone missiles will result in widespread harm through large explosions.

In actuality, because of the size of the drones in direct relation to the size of the missile they can carry, largescale explosions will only occur with multiple successive strikes. Hellfire missiles, for instance, are one of the 
largest drone missiles but have a restricted blast radius of 10 - 15 feet, from which they can be detonated on a timer (Matthews \& McNab, 2011). This proves useful for determining "the final opportunity" and ideal firing conditions of the operator. This allows for implementation of precautionary measures, which will be discussed in the coming sections, such as waiting until the targeted individual exits a building occupied by civilians to minimize risk. For example, one news report describes the precision of drones in operation as within the same building, a drone fired upon and killed terrorist targets in one room whilst leaving civilians in the adjoined room unharmed (Jones, 2014).

\subsection{General Use of Drones}

The lower cost of production, the resource efficiency, and the overall capabilities of drones provide several key reasons why many States now seek to increase their drone arsenals. Indeed, for these same reasons, drones appeal to non-State actors as well. For instance, the United Nations (UN) has employed drones to facilitate humanitarian missions, such as aerial surveillance in the Democratic Republic of the Congo (UN Launches, 2014) (UN Starts, 2013). These operations exist in parallel to conflict operations with the practical usage of using drones to drop humanitarian supplies in troubled (e.g. natural disasters, armed conflict) areas as briefly discussed earlier. Increasing popularity for this method predicates upon the drone's allowance for greater surgical precision for the drops in difficult or dangerous flying areas. It also lowers mission costs as the troops do not need to be deployed as the aircraft can be remotely piloted.

Alternatively, many speculations about drones, which this author argues have resulted to an extent in misinformation, point to the US or even Israel as the two main users of drones. The US and Israel are perhaps the two States most speculated as the sole users of drones (Israel's Defence, 2014), however, while they are possibly the two primary users, there are more than 40 other countries competitively developing and employing drone technology (Alston, 2010). As a result, discussions on drone development largely pertain to assessment of drone legality as linked with the main uses of drones.

Drones are thought to be inherently unlawful as they are directly associated with targeted killing policies advocated by States such as the US, Russia, and Israel generally as responses against terrorist attacks (Matthews \& McNab, 2011). Thus, the inherent problem associated with the legality of drones—as is with all weapons-is when they can be lawfully employed and against whom. If States employ drones as a counter-terrorism policy, this proves problematic in light of the nebulous legal minefield associated with the discourse of terrorism itself. While this paper will not address the use of drones in these contexts (contexts which are outside of international warfare), it does point out that these remain imperative issues which, nonetheless, continue to be governed by domestic and human rights laws.

\section{Jus in Bello and IHL}

Drones, by themselves, are not illegal. They do not qualify as banned military instruments under regulations of armed conflict nor under Article 8 of the Rome Statute as they do not exhibit banned qualities such as causing indiscriminate harm or unnecessary suffering (Schmitt, 2011). However, lawful action of drones rests upon customary principles such as military necessity and proportionality—with due regard for protection of civilians and civilian objects (Vogel, 2011; Military Commander, 2012; Air Force Operations, 2009). As mentioned earlier, in linkage to their common usage, the lawful firing of drone missiles predicates upon the status of the target (Schmitt, 2011).

In addition to the general prohibition on the use of force, there exist established rules which govern warfare in the event of conflict. For example, under customary laws, indiscriminate weapons are prohibited, an issue that affects the implementation of drones rather than the weapon itself (Military Commander, 2012). Applicable rules which govern conflict activities are international humanitarian laws codified in the 1946 Geneva Conventions, the 1907 Hague Conventions, the 1977 Additional Protocols, and interlinked to the three aforementioned, customary international law (Cryer, Friman, Robinsin, \& Wilmshurst, 2007).

Legal regulations allowing use of drones appear fairly straightforward ${ }^{1}$-if in compliance with international laws regulating force, deployment of drones is allowed. Otherwise, the legal uncertainty follows from case law where few courts have expressly or consistently issued judgments on drones, for instance in relation to targeted killing. If employed as a weapon (as opposed to surveillance or intelligence usages) the legality of the use of

\footnotetext{
${ }^{1}$ This author would like to point out that the straightforward quality mentioned pertains strictly to international armed conflicts.
} 
drones largely predicates on targeting restrictions. Overall, the dichotomy between combatant and non-combatant or civilian status, and collateral damage in relation to proportionality exemplify several IHL restrictions which inform the lawfulness of targeting (Cryer, Friman, Robinsin, \& Wilmshurst, 2007). In addition, restrictions on launching missiles extend from civilian protection of humans to protection of civilian objects as well, such as churches or cultural buildings (Kalshoven \& Zegveld, 2011).

As a fundamental rule, IHL prohibits targeting civilians and non-combatants (Cryer, Friman, Robinsin, \& Wilmshurst, 2007) found in both Additional Protocol I (AP I) and the fourth Geneva Convention of 1949 (Kalshoven \& Zegveld, 2011). Importantly, IHL prohibits indiscriminate attacks (Vogel, 2011) as well as attacks which directly target civilians or civilian objects (Gill \& Fleck, 2010; Kalshoven \& Zegveld, 2011; Military Commander, 2012). IHL holds restrictions upon warfare, wherein it essentially seeks to prevent unnecessary harm or otherwise, any actions deemed beneath human dignity. Indeed, specific rules pertaining to aerial warfare, found in the guidelines of the Hague Rules on Aerial Warfare, uphold these principles in which this convention expressly prohibits aerial bombings of targets other than military objectives (Hague Rules, 1923). However, as IHL developed in attempt to regulate warfare, acknowledgement that casualties and other harm remains as a predictable consequence. As such, "destruction and death will occur even in lawfully conducted conflict” (Cryer, Friman, Robinsin, \& Wilmshurst, 2007).

While these regulations exist, they have not necessarily been expanded upon by international legal forums. In particular, the use of drones to date has not been litigated upon by international courts. As such, these next two sections will evaluate existing jurisprudence before the International Court of Justice (ICJ) and the International Tribunal for the former Yugoslavia (ICTY) which address and engage with IHL before international courts and thus provide useful guidance for lawful use of drones. The ICJ section will set out general prohibitions that could relate to the function and usage of drones. The ICTY section will evaluate the ICTY report by the Committee to review the aerial strikes used by the North Atlantic Treaty Organization (NATO) within the former Federal Republic of Yugoslavia from March until June 1999.

\subsection{International Legal Jurisprudence on IHL-The ICJ and Indiscriminate Weapons}

As mentioned before, the activities of warfare are not without limitations. Weaponry is not unlimited, tactics are restricted, and altogether there are principles which constrain the behaviour of belligerents involved-these limitations are fulfilled by the pivotal role of IHL. However, as modes of warfare change and evolve, regimes governing the means and methods of warfare must also adapt to afford safeguards and protections to those involved as well as those affected by the conflict. The ICJ discussed these safeguards regarding humanitarian principles, where it upheld in the Nuclear WeaponsAdvisory Opinion that weaponry available for use by the parties is not unlimited. The Courted cited the principle of distinction as a cardinal rule of IHL (Gill \& Fleck, 2010). For instance, attacks which cannot discern from lawful and unlawful targets (meaning military and civilian objects respectively), are prohibited (Cryer, Friman, Robinsin, \& Wilmshurst, 2007). This demonstrates a key principle that weapon deployment in conflict must be intended for legitimate combat purposes, meaning actions pursued must be pursuant to achieving military purposes.

In addition, in the Nuclear WeaponsAdvisory Opinion the Court contended that "States must never make civilians the object of attack and must consequently never use weapons that are incapable of distinguishing between civilian and military targets" (Nuclear WeaponsAdvisory Opinion, 1996). In relation to this topic regarding drones in warfare, it is contended that while drones provide improved accuracy capabilities, like every weapon, they fundamentally aim to harm. As such, while they do not fall under inherently indiscriminate weapons (Nuclear Weapons Advisory Opinion, 1996) they could nonetheless be used indiscriminately and as such could incur culpability for breaches of IHL regulations.

In light of the fact that drones are often employed in areas that are complicated by difficult flying conditions and or otherwise considered dangerous or risky situations, using drones may aid the precision of the mission's objective. However, if its mission is for armed sorties, then this aim would not be without risk of harming, either indirectly or incidentally, civilians. Indeed, in her dissenting opinion, Judge Higgins discusses this dilemma and does argue that if executing a legitimate target would cause additional harm, this act would not be prohibited (Higgins Dissent, 1996). Overall, the legality of the strikes would predicate on the respect of proportionality and the weight of the anticipated harm against the anticipated military advantage; incidental harm is lawful only if it is not excessive in nature (Higgins Dissent, 1996; Gill \& Fleck, 2010; Kalshoven \& Zegveld, 2011; Cryer, Friman, Robinsin, \& Wilmshurst, 2007). This balancing of objectives leads into foreseeability and intent issues, 
which will be addressed in the next chapter.

\subsection{International Legal Jurisprudence on IHL-The ICTY and Aerial Bombardments}

In addition to the ICJ, the ICTY has also expanded upon principles of the laws of armed conflict but does so from within the scope international criminal law. This paper will use the report issued to the prosecutor addressing NATO aerial bombardments in Kosovo as an analogous example to the use of drones in international warfare. From 24 March until 9 June 1999 NATO conducted aerial sorties over the Yugoslavian territory. These strikes were subsequently criticized for excessive casualty results, the majority of which were civilians, which Amnesty International, amongst others, alleged resulted in breaches of IHL (Final Report, 2000).

Amnesty International released a report to the tribunal to explain and defend its reasoning that NATO committed war crimes in its aerial bombardment campaign. It argued that in NATO's 38,000 combat sorties and 10, 848 strike sorties, roughly 400 to 600 civilians were killed (Amnesty International, 2000). It concluded by stating it believed "civilian deaths could have been significantly reduced if NATO had fully adhered to the laws of war. NATO did not always meet its legal obligations in selecting targets and in choosing means and methods of attack" (Amnesty International, 2000).

While Amnesty International contended that casualties are realities of war, they rightfully argued that direct attacks on civilian objects and excessive civilian harm due to failure to take precautionary measures constitute war crimes. One example which Amnesty International discussed was NATO's alleged failure to distinguish its targets from civilian to military objectives, resulting in indiscriminate aerial bombing. A partial reason for this indiscriminate use of aerial bombing was the change in altitude to avoid risking the pilot (Amnesty International, 2000) leaving the onus of risk on the civilians below as flying at higher altitudes lessons visual clarity.

Failure to give efficient warnings, failure to suspend or alter attacks after ground circumstances changed, and failure to distinguish between military and civilian targets embody three key characteristics the report contended embodied war crimes (Amnesty International, 2000). Interestingly, Amnesty found that only a third of the weapons used by NATO's aerial bombing campaign were precision-guided munitions, and of those $33 \%$ of munitions, only 70\% effectively reached their desired target (Amnesty International, 2000).

While the investigations by the ICTY committee ultimately did not find that NATO committed war crimes, it did provide useful elaboration on circumstance where aerial bombardments could constitute war crimes (Final Report, 2000). The committee re-iterated the premise that indiscriminate attacks are fundamentally unlawful but also elaborated on the negative impact of aerial bombardments, for example, on the natural environment (Final Report, 2000). It also assessed how sufficient use of precautionary measures (such as target verification, a matter discussed in chapter IV) demonstrates lack of intent or objective purpose to cause harm, either with negligence or recklessness (Final Report, 2000).

This provides a comparison with that of drones, which possess improved capabilities since the late 1990s, and consequently could aid in greater precision mechanisms. For instance, a key reason NATO pilots flew higher, potentially decreasing targeting efficiency, was due to danger of being targeted themselves from ground forces and so on - with drones, this risk substantially decreases, especially as the pilot's life is not in immediate danger in the mission. As such, the ICTY committee did find that NATO was obligated to take precautionary measures in distinguishing targets, but the committee did not find that NATO aerial bombardments failed this obligation simply due to flying higher as other technology was used to verify that which could not be done with the naked eye (Final Report, 2000). However, despite technological improvements with drone capabilities, it nonetheless remains for the pilot and commander to effectively issue judgements in determining lawful conditions for executing missile launch (Final Report, 2000). Thus, a key qualification for war crimes resulting from breaches of IHL rests upon either intent or recklessness in causing harm, which was elaborated upon in the ICTY report (Final Report, 2000).

\subsection{General State Practice and Drones in Compliance with IHL}

While it is doubtful to think drones were invented with a humanitarian consciousness over say, military advantage, they do provide States with improved capabilities for targeting discrimination (Lewis, 2012) ${ }^{2}$. The factual qualities of drones described earlier, their accuracy (both in context and in targeting) provide improved mecha-

\footnotetext{
${ }^{2}$ Lewis argues the alternative, stating “The driving force behind the western militaries' development of drone technology was to minimize the number of human lives placed at risk...”
} 
nisms for compliance with IHL (Schmitt, 2011; Lewis, 2012). The evolution of weaponry development, such as the emergence of drones, could provide States with improved methods for IHL compliance. For example, drones have specialized, focused targeting mechanisms, which sufficiently meets the "capable of discriminate attacks" criteria (Schmitt, 2011). However, that is not to say that States fulfil their IHL obligations and use drones purely within lawful activities, but drone actions resulting in violations of IHL are more often deliberate actions which will be discussed in the following section.

Prohibitions governing indiscriminate attacks do not, however, mean that any attacks which cause harm to civilians are forbidden, but rather indiscriminate attacks which fail to distinguish between combatants and civilians would be disallowed (Gill \& Fleck, 2010). This distinction theoretically could be complied with and still result in incidental, but legal harm to civilians if the attack was not carried out directly against the civilians but the harm occurred incidentally under proportionality and necessity criteria (Gill \& Fleck, 2010). This again demonstrates the potential effectiveness of utilizing drone technology whereby the accuracy in targeting combined with the play-by-play data sent to the pilot allows for firing the missiles only when the "window of opportunity" meets IHL criteria.

Also helpful is to demonstrate that those who use drones (for this paper, this strictly pertains to a State's apparatus) as in those responsible for flying them and firing the weaponry from remote locations, receive training and are informed of IHL laws - something that the media and academia either disregards or perpetuates ignorance of. This is partly due to the secrecy or transparency deficit with State defensive units, intelligence, military capabilities, and general extra-territorial defensive operations fall under the continued dogmatic "shield" of State sovereignty (Schmitt, 2011). What attention is brought to the issue falls more often under unfortunate failures or mistakes than of a balanced perspective of successes - this again relates to the lack of transparency, where defensive departments are reluctant to share information regarding their operations, leaving them open to criticism by the international community.

IHL is addressed to States, requiring the belligerent parties involved to inform and enforce (and if need be, to punish) compliance with established rules of war. However, war crimes are perpetrated by individuals, whether under criminal liability as an accessory to the crime, as a commander, or as a primary perpetrator. Legally, pilots of drones, whether via civilian intelligence or contractors, are considered to have unprivileged participant status for the duration of their targeted drone killing activities (Lewis, 2012; Alston, 2010; Vogel, 2011). This is significant as it makes them lawful targets for the temporal scope of their participation (Alston, 2010).

\section{Drones, Jus in Bello, and War Crimes under ICL}

This next section analyses how the use of drones could constitute war crimes' which are grave breaches of the Geneva Conventions (Gill \& Fleck, 2010) within the context of Article 8 of the Rome Statute. Article 8 (1) of the Rome Statute reads "The Court shall have jurisdiction in respect of war crimes in particular when committed as part of a plan or policy or as part of a large-scale commission of such crimes” (Rome Statute, 1998). Thus to trigger prima facie requirements under this opening provision, the alleged crimes in question would require a plan or policy or a large scale commission of the acts, although an individual crime can also constitute a war crime (Cryer, Friman, Robinsin, \& Wilmshurst, 2007). However, in its analysis of drones fulfilling war crimes criteria, this paper will restrict its evaluation to war crimes falling under Article 8 (2) (a) and 8 (2) (b). These sections specifically pertain to conflicts of an international character.

According to the Rome Statute, an additional requirement exists for an act to constitute a war crime. For there to be an act qualifying as a war crime under Article 8 there requires a nexus criteria linking the crime with an armed conflict, either an international armed conflict (IAC) or a non-international armed conflict (NIAC) (Cryer, Friman, Robinsin, \& Wilmshurst, 2007). More generally, to trigger jurisdiction of the Court itself, this requires three methods outlined in Article 13 as 1) a State party refers a situation to the Court, 2) the UN Security Council refers a situation to the Court, or 3) for the Prosecutor to act propriomotu. These correspond to Articles 13, 14, and 15bis and 15ter which elaborate on these provisions (Rome Statute, 1998).

Under Article 8 (2) (a) the Statue incorporates established IHL law taken from the 1949 Geneva Conventions and other relevant established international law (Cryer, Friman, Robinsin, \& Wilmshurst, 2007). Core provisions of IHL ban indiscriminate targeting practices, including weaponry which are incapable of distinction (Gill \& Fleck, 2010). However, this distinction holds an overall caveat in international conflicts, as in these types of conflicts there are two categories of persons: combatants and civilians. Each category are afforded aspects of 
protections, but under some acts, such as wilful killing, these are crimes only against non-combatants (Cryer, Friman, Robinsin, \& Wilmshurst, 2007).

As IHL argues that whoever does not qualify as a combatant automatically qualifies as a civilian (Gill \& Fleck, 2010) customary law and State practice exist in a current State of flux regarding non-State armed groups in international conflicts and also terrorist actors. However, this paper will explain how under existing IHL, for which violations under the Rome Statute can arise, terrorists and non-State actors continue to constitute protected civilians. Exceptions to this rule allow for legitimately targeting civilians should the civilians in question actively and directly participate in combat (Kalshoven \& Zegveld, 2011). However, lawfulness of targeting these civilians pertains strictly to the duration of their active involvement.

The factual nature of drones_-as an instrument capable of but not restricted to purposes of force-provides imperative evaluation for potential allegations of international core crimes, such as war crimes or crimes against humanity. States deploy drones for three interrelated reasons 1) efficiency, 2) accuracy, and 3) prevention or protection of human risk. As indicated in the previous section, these objectives also potentially implicate mens rea elements for judicial hearings. Because of the precision of drones, both from the accuracy of data procured to inform the pilot and the relative accuracy of the targeting itself, any crimes resulting from drone sorties could demonstrate either an intent to disregard the laws of war by means of recklessness or negligence, or a direct culpability for knowingly firing upon unlawful targets.

Regarding liability, actual launching of drones ultimately rests upon a leadership decision. This implicates liability under command responsibility, or liability under Article 28 of the Rome Statute, as it is the commanders who give the final authorization for the order (Air Force Operations, 2009). For example, precautions must be taken when giving orders to exercise drone strikes, thus, if the status of the target is doubted (in terms of being military or combatant), then the assumption is the target is civilian and is protected and must not be attacked (Gill \& Fleck, 2010; Kalshoven \& Zegveld, 2011; Military Commander, 2012; Cryer, Friman, Robinsin, \& Wilmshurst, 2007).

\subsection{Drones and Proportionality under the Rome Statute}

While this paper has extensively analysed the lawfulness of certain targets, a related issue of lawful drone action is the resulting damage from the strikes. While it is clear that prohibitions on directly targeting civilians exists, States are also prohibited from executing strikes which would predictably or knowingly cause excessive or unnecessary civilian harm (Kalshoven \& Zegveld, 2011). Thus, war crimes may result from strikes if the results failed proportionality tests.

Generally the proportionality test weighs potential harm against military benefit (Gill \& Fleck, 2010). It is a test decided by the commander prior to the launched sorties and must be decided for each and every attack (Matthews \& McNab, 2011). Michael Schmitt clarifies that the weapon used proves irrelevant, but rather the issue is whether "expected civilian casualties or damage were excessive relative to the military gain the attacker reasonably anticipated from the strike” (Schmitt, 2011). The evaluation of proportionality by courts results in inconsistent determinations as proportionality is assessed subjectively by the military apparatus (usually a commander giving a final “go" order) and is difficult to objectively quantify or qualify (Air Force Operations, 2009; Cryer, Friman, Robinsin, \& Wilmshurst, 2007).

Proportionality is considered prior to launching an attack but is again evaluated after the fact, often by different actors than the ones considering the initial attack. As proportionality must be determined for each individual attack, and as each attack carries different factors to be weighed (such as the nature of the target, circumstances, weaponry available, etcetera), this complicates attempts at legal certainty for subjective or objective determinations of, for instance, what constitutes “excessive” under the framework of proportionality (Matthews \& McNab, 2011; Cryer, Friman, Robinsin, \& Wilmshurst, 2007). Harm resulting from drones does not negate its lawfulness under principles of proportionality (Matthews \& McNab, 2011; Schmitt, 2011), but it is the qualification of the numbers which provides uncomfortable calculations. As such, while there are certainly more clear concepts within IHL, proportionality is not one of them. It remains an evaluation on a case-by-case basis as (Vogel, 2011) " $[\mathrm{t}]$ he main problem with the principle of proportionality is not whether or not it exists but what it means and how it is to be applied” (Final Report, 2000).

Strikes may be ordered with legitimacy in mind, but legitimacy does not equate to lawfulness-those in authority for the planning and decision making of the attacks are obligated to uphold preventative and protective measures against needless civilian harm, even if this harm would be caused incidentally (Kalshoven \& Zegveld, 
2011; Military Commander, 2012). That being said, drones are not flawless mechanisms of war. Humanitarian "[l]aw does not require perfection in the execution of a military attack nor does it prohibit all civilian casualties" (Matthews \& McNab, 2011). Armed conflict will inevitably result in loss of life, but the parties to the conflict are under conventional and customary obligations to prevent unnecessary harm. Drones possess improved mechanisms to facilitate discrimination capacities for targeting, but war crimes could result if these capabilities are misused.

\subsection{Drones, Targeted Killings, and ICL}

The use of drones to implement targeted killing policies presents a key area of drone use which affects international and non-international conflicts alike. This paper ventures that this usage of drone technology poses a plausible example of drones constituting war crimes within the meaning of Article 8 of the Rome Statute. It is acknowledged that targeted killing policies are perceived to affect NIACs more commonly than IACs. However, the increasing role of non-State actors in conflicts, in particular complication of non-sanctioned participation of civilians, demonstrates on-going concerns which pertain equally to international as well as non-international conflicts. As such, IHL (particularly Common Article 3 of the Geneva Conventions), customary international law and international human rights continue to apply to all forms of armed conflict, regardless of designation as international or internal. (This author strongly notes that IHL and international human rights law apply lexspecialis in conjunction with human rights.)

Nonetheless, international human rights law would be the applicable legal framework for drones used to fulfil targeted killings outside of armed conflicts. (This author strongly notes that IHL and international human rights are not mutually exclusive but rather, IHL applies as lexspecialis in conjunction with human rights.) While this paper will not engage with the latter, it uses this statement to point out that even absent an armed conflict, use of drones as lethal force still falls under a compatible legal framework (O'Connel, 2011). If States employ military force which falls outside the scope of armed conflicts or self-defence, then these operations are governed by the human rights paradigm; where IHL gaps exist—international human rights law fills in (Matthews \& McNab, 2011).

Moreover, this paper rejects the category of unlawful combatants as this concept fails to compatibly and consistently apply to established rules of IHL. The (contested) category of unlawful combatants largely relates to counter-terrorism policies by States. These States, particularly, Russia, the US, and Israel, argue that unlawful combatants are individuals who under IHL would generally be deemed civilians, but because of their affiliation with non-State armed groups, are deemed to have active combatant roles (Gill \& Fleck, 2010). As combatants are authorized by their respective States, these third category of individuals are combatants who are not sanctioned as members of armed forces, thus their participation in hostilities is rendered unlawful (Gill \& Fleck, 2010).

While this category perceptively makes State policies more legitimate, outside of theory they fail to uphold legal standards. This rests upon several inter-related reasons. First, in IHL there are two categories: combatants and civilians. Second, the distinction as a combatant means that the State for which the individual(s) are fighting authorizes them to fight. With the distinction of an unlawful combatant, this is decided by third party States and not by the State of the individual's origin or nationality.

This proves problematic for several reasons, one main reason being that the third party (for example, Russia, the US, or Israel) labels an individual as an unlawful combatant for the purposes of targeting them-which predicates largely on allegations of, for instance, terrorist membership or association with a particular organization. One example of this in practice is the characterization of an individual as fulfilling "continuous combat function". This characterization forfeits the individual's immunity from attack exclusively based upon group membership (Lewis, 2012). Yet without processes of verification, or objective standards, this presents a highly contested practice which, in the author's opinion, fails to comply with the objective purpose of IHL-which is to protect those engaging and effected by conflict, and to limit the means and methods of warfare. In opposition to this, the unlawful combatant category seeks to broaden methods of warfare and allow for more inclusive methods of targeting.

Third, this author contends that the unlawful combatant category is inherently unnecessary. There already exist compatible designations allowing States to target civilians under certain circumstances without unnecessarily enlarging the scope of lawful targets. While civilians overall are entitled to protective status, they are not absolutely prohibited from being targeting under certain conditions. These conditions include direct and active en- 
gagement in combat, for which the person loses their immunity and can be lawfully targeted for the duration of this engagement (Gilll \& Fleck, 2010; Lewis, 2012; Vogel, 2011; Kalshoven \& Zegveld, 2011). However, this author acknowledges what constitutes "active", "direct" and "for the duration" can prove problematic in practice, complications arising from this fail to negate the continued status of the civilian (Kalshoven \& Zegveld, 2011). In 2009 the ICRC issued Interpretive Guidance on the Notion of Direct Participation in Hostilities; while useful, its authoritative force is questioned.Ultimately, civilians engaging actively and directly lose their protection in that they can be lawfully targeted during their engagement with the conflict, but this does not abolish their overall status as civilians (Gill \& Fleck, 2010).

The Israeli Supreme Court provided insight into targeting restrictions as it decided upon the targeted killing issue in its evaluation of the legality of Israel's targeted killing policy. In its conclusion the Court confirmed that the status of a target being lawful or unlawful resides on a contextual case by case basis and should be evaluated retroactively by an independent party (Targeted Killings, 2005). Indeed, Judge Rivlin stated one "cannot determine in advance that targeted killing is always illegal” (Targeted Killings, 2005). Overall, while the judgement failed to provide more broadly applicable legal analysis, it did provide clarification that the current State of international law does not recognize the category of unlawful combatants (Targeted Killings, 2005).

As such, States that employ drones to target individuals under the guise of the category of unlawful combatants usually do so under systematic elimination of these targets through the use of drones. Therefore, this systematic elimination, as a State policy, fulfils the criteria of Article 8 of the Rome Statute and results in the commission of war crimes. Under the Geneva Conventions, civilians who engage in armed conflicts are acting unlawfully as by definition they are acting without State authorization. As a result, they can be tried for illegally participating in the conflict.

However, if States target civilians who participate in conflict under the justification of labelling these actors as unlawful combatants, this denies them their civilian status under Article 8 (2) (a) (vi) which affords them the right to a fair trial (ICC Elements, 2002). In addition, these targeting policies demonstrate intentional attacks against civilians within the meaning of Article 8 (2) (b) under the provisions of (i-v) which includes intentionally directed attacks against the civilian populations or civilian objects and otherwise knowingly and intentionally attacking targets where civilian or civilian objects will be foreseeably harmed or damaged (ICC Elements, 2002).

\subsection{Drones, Precautionary Measures, and ICL}

While drones could be used as weaponry of heightened precision, and as such could qualify as taking precautionary measures to prevent excessive harm (Schmitt, 2011), miscalculations or disregard for on-the-ground situations could nonetheless result in war crimes (Cryer, Friman, Robinsin, \& Wilmshurst, 2007). For instance, murder (Article 8 (2) (a) (i)) and otherwise causing excessive damage (Article 8 (2) (b) (iv)) constitute war crimes which could result from drone strikes. IHL requires the attacker to implement reasonable verification measures and in circumstances where the legality of the strike's objective is dubious, requires the cancelation or suspension (as indicated in Additional Protocol I, Article 57 (2)) of the strike (Kalshoven \& Zegveld, 2011; Hague Rules, 1923). This balances against the requirement to evaluate proportionality as the strike must have concrete and direct military advantage, not merely speculated or hopeful—civilian harm must be avoided (Gill \& Fleck, 2010).

An example of precautionary methods available with drones is target verification using technology such as imagery and loitering capabilities, as was discussed earlier. Visual feedback of the drone's camera allows for multiple authority figures to evaluate the data. In practice, this means that "[t]he drone's sensors allow many sets of eyes, including those of [Judge Advocate General] lawyers trained to assess proportionality, to make a proportionality determination at the time of weapons release” (Lewis, 2012).

Civilian harm in itself does not constitute a war crime, but rather, a war crime is committed when the drones were employed with reckless or excessive attacks (Vogel, 2011). Wilful killing and murder results if the missiles are launched from drones when IHL precautions are not taken or are disregarded. Thus, unarmed drones could be used as a precautionary method if used to gather intelligence to verify targeting information, but would be employed illegally if armed drones are used when less harmful methods are available (Schmitt, 2011)—drones may carry smaller missiles, but the results are no less accountable.

An example of aerial bombings and precautionary measures used in practice is the 1999 NATO aerial bombings discussed earlier. These bombings were criticized for executing strikes with higher altitude ceilings which 
decreased efficiency for targeting, as flying higher complicates visibility (Amnesty International, 2000). In light of this example, evolution of drone technology could prevent this issue in the future as drones can fly at lower altitudes to gather improved targeting data with decreased risk of harm to the pilot. Flying at lower levels with minimized risk to pilot and civilians alike would allow for less risky gathering of substantial information regarding the ground situation (Matthews \& McNab, 2011). This could exemplify a precautionary measure as employing drone use in this instance compares to capabilities usually unavailable for ordinary aerial bombings by larger aircraft.

Furthermore, an important precautionary measure to implement is the obligation to issue, where permissible, warnings of impending strikes as elucidated under Article 26 of the (Hague Convention II, 1899). As seen with the NATO bombings discussed above and in prior sections, a consistent criticism of the legality of drone use predicates on the failure to give prior warnings to civilian populations. Prior warning of impending attacks is a requirement under Article 57 (2) (c) of Additional Protocol I and Article 26 of the II Hague Convention. In practice, the use of drones for surprise attacks has meant that strikes are often done with no forewarning (Vogel, 2011), yet the lawfulness of these strikes would then rest upon whether effective forewarnings were available and viable options to the attacker.

Nonetheless, it is imperative to remember that any perceived precautionary measures available with drone usage or any perceived benefits to prevent collateral damage and other harm rests entirely on the quality and accuracy of intelligence received (Alston, 2010; Knoops, 2012). While drones possess camera technology to send information to the pilots itself as raw data, all too often intelligence relied upon derives from secondary sources (Knoops, 2012). Intelligence collected from the drone are not flawless either. One practical example raised is the issue of surrender and mistakenly targeting those of hors de combat status, where it would be difficult for a drone operator to alter the drone's actions to facilitate a declaration of surrender (Vogel, 2011).

While it has been argued that drones do present mechanisms which facilitate greater discrimination features for warfare, it remains "incumbent upon a drone operator and commander to exercise judgment in determining when to conduct an attack where there are co-located civilians or where the targets themselves are difficult to identify" (Vogel, 2011; Air Force Operations, 2009). The collateral damage is lawful if proportionate, but prior to the results, it is required upon the commander and the operator to minimize, wherever possible, foreseeable harm to civilians and civilian objects (Kalshoven \& Zegveld, 2011; Military Commander, 2012; Air Force Operations, 2009; Hague Rules, 1923). Targeting is inherently a responsibility of command function requiring "commander oversight and involvement to ensure proper execution" (Air Force Operations, 2009). As such, this expresses the commanders' responsibility under Article 28 of the Rome Statute for war crimes committed using drones.

\subsection{Drones and Terror under ICL}

As a final example of how drones could embody violations of Article 8 war crimes, the causing of terror towards civilian populations will be briefly explored. Additional Protocol I, Article 51 (2) prohibits terrorizing civilian populations. Deficient definitions of terrorism aside, the author finds that it is understandable that the buzzing heard from drones can cause fear or terror, particularly as those who hear the drones will be unaware as to know whether the drones are armed or not. Factual uses of drones discussed earlier also could be seen to induce terror or fear into civilian populations as drones are used for reconnaissance, meaning they follow, hover over, and maintain visual connections with their targets. For family members, neighbours, and ordinary civilians, this could result in violations of personal dignity and general concern for safety and welfare. In addition, as Article XXII of The Hague Rules of Aerial Warfare expressed "Aerial bombardment for the purpose of terrorizing the civilian population, of destroying or damaging private property not of a military character, or of injuring noncombatants is prohibited" (Hague Rules, 1923). This demonstrates that use of aerial warfare to terrorize civilian populations continues to present an issue-and a war crime-in international conflicts.

However, violations of Article 51 (2) and Article XXII of the Hague Rules do not expressly compliment provisions under the Rome Statute as such, unless interpreted broadly under provisions of outrages upon personal dignity or inhumane treatment (Rome Statute, 1998). First, this author contends that drones could result in the effect of terrorizing civilian populations, but this would require unnecessarily broad interpretations of the Rome Statute and would perhaps more appropriately fall under crimes against humanity rather than war crimes. However, this author does acknowledge that the ICTY, particularly the Galić cases, have dealt with inducing terror 
amongst civilians as a war crime (Cryer, Friman, Robinsin, \& Wilmshurst, 2007). Second, the prohibition of terrorizing civilian populations does not encompass incidental terrorization, meaning that to violate prohibitions the attacks would require the terrorization of civilians as a purported objective (Gill \& Fleck, 2010; Cryer, Friman, Robinsin, \& Wilmshurst, 2007).

However, it is briefly noted that incidental harm could relate to indiscriminate usage as non-State actors can prove difficult to distinguish by blending in with larger civilian populations. On a peripheral note, drones do not have defensive mechanisms per se, thus they are vulnerable to potential jamming frequencies which cause interference with their remote piloting feed (Lewis, 2012). In practice this means that those on the ground possess abilities to destroy drones in progress, ultimately meaning that locals are not without hypothetical defences.

\section{Conclusion}

This paper has argued that while drones are not without issues, and indeed their use could result in commission of international criminal offenses; they fit within compatible existing legal frameworks such as IHL and customary law. Essentially, it is not whether or not there are laws sufficient to govern the facilitation of drone use but whether these existing laws are compliantly followed (Vogel, 2011). While acknowledging flaws with drone use, this paper has in part sought to illuminate common areas of misconception with academics and legal scholars on the legality of drone use. While this paper has argued that drones do not represent an ungoverned phenomenon of weaponry, it will contend that use of drones by non-State actors, such as armed groups, does continue to pose a present concern. Ultimately, if the target is lawful, the weaponry platform used to deliver the attack is irrelevant (that is, unless the weapon itself is not prohibited under IHL). Just as an outbreak of war fails to result in a legal vacuum, so too does the development of new weaponry fail to result in a legal void.

\section{Acknowledgements}

Special gratitude to Debora, A. for her invaluable editing remarks and general support.

\section{References}

Alston, P. (2010). Report of the Special Rapporteur on Extrajudicial, Summary or Arbitrary Executions. Philip Alston: United Nations General Assembly, Human Rights Council, A/HRC/14/24/Add.6.

Amnesty International (2000). NATO/Federal Republic of Yugoslavia “Collateral Damage” or Unlawful Killings? Violations of the Laws of War by NATO during Operation Allied Force. AI Index: EUR 70/18/00. (Cited as: Amnesty International)

Convention (I) for the Amelioration of the Condition of the Wounded and Sick in Armed Forces in the Field. Geneva, 12 August 1949; Convention (II) for the Amelioration of the Condition of Wounded, Sick and Shipwrecked Members of Armed Forces at Sea. Geneva, 12 August 1949; Convention (III) relative to the Treatment of Prisoners of War. Geneva, 12 August 1949; Convention (IV) relative to the Protection of Civilian Persons in Time of War. Geneva, 12 August 1949. (Cited as Geneva Conventions I-IV)

Cryer, R., Friman, H., Robinsin, D., \& Wilmshurst, E. (2007). An Introduction to International Criminal Law and Procedure (2nd ed.). Cambridge: CUP. http://dx.doi.org/10.1017/CBO9780511801006

Final Report to the Prosecutor by the Committee Established to Review the NATO Bombing Campaign Against the Federal Republic of Yugoslavia (2000). http://www.icty.org/sid/10052 (Cited as: Final Report)

Gill, T. D., \& Fleck, D. (2010). The Handbook of The International Law of Military Operations. Oxford: OUP.

Hague Convention (II) with Respect to the Laws and Customs of War on Land and Its Annex: Regulations Concerning the Laws and Customs of War on Land. The Hague, 29 July 1899. (Cited as: Hague Convention II)

Hague Rules of Aerial Warfare (1923). http://lawofwar.org/hague_rules_of_air_warfare.htm (Cited as: Hague Rules)

ICC (2002). Elements of Crimes of the International Criminal Court, UN Doc. PCNICC/2000/1/Add.2. (Cited as: ICC Elements)

ICC (1998). Rome Statute of the International Criminal Court, UN Doc. 2187 UNTS 3. (Cited as: Rome Statute)

ICRC (1977). Protocol Additional to the Geneva Conventions of 12 August 1949 and Relating to the Protection of Victims of International Armed Conflicts (Protocol I), 8 June 1977, 1125 U.N.T.S. 3.

International Court of Justice (1996). Legality of the Threat or Use of Nuclear Weapons. Advisory Opinion, ICJ Report 679, 226. (Cited as: Nuclear WeaponsAdvisory Opinion) 
Jones, O. B. (2014). Drones or UAVs? The Search for a More Positive Name. http://www.bbc.com/news/magazine-25979068?ocid=socialflow_twitter

Judge Advocate General's School (2009). Air Force Operations and the Law: A Guide for Air, Space and Cyber Forces. US Air Force. (Cited as: Air Force Operations)

Judge Rosalyn Higgins (1996). Legality of the Threat or Use of Nuclear Weapons: Dissenting Opinion of Judge Higgins. Advisory Opinion, ICJ Report 679, 583. (Cited as: Higgins Dissent)

Kalshoven, F., \& Zegveld, L. (2011). Constraints on the Waging of War: An Introduction to International Humanitarian Law. Cambridge: Cambridge University Press. http://dx.doi.org/10.1017/CBO9780511995231

Knoops, G. J. A. (2012). Legal, Political and Ethical Dimensions of Drone Warfare under International Law: A Preliminary Survey. International Criminal Law Review, 12, 697-720. http://dx.doi.org/10.1163/15718123-01204004

Leander, A. (2013). Technological Agency in the Co-Constitution of Legal Expertise and the US Drone Program. Leiden Journal of International Law, 26, 811-831. http://dx.doi.org/10.1017/S0922156513000423

Lewis, M. W. (2012). Drones and the Boundaries of the Battlefield. Texas International Law Journal, 47, $299-300$.

Matthews, M., \& McNab, M. (2011). Clarifying the Law Relating to Unmanned Drones and the Use of Force: The Relationships between Human Rights, Self-Defence, Armed Conflict and International Humanitarian Law. Denver Journal of International Law and Policy, 39, 661.

O’Connell, M. E. (2011). Remarks: The Resort to Drones under International Law. Denver Journal of International Law and Policy, 39, 585.

Schmitt, M. N. (2011). Drone Attacks under the Jus ad Bellum and Jus in Bello: Clearing the "Fog of Law”. Yearbook of International Humanitarian Law, 13, 311-326. http://ssrn.com/abstract=1801179

The Israeli Supreme Court, Sitting as the High Court of Justice (2005). “Targeted Killings”, Petition for an Order Nisi and an Interlocutory Order, HCJ 679/02, 11 December 2005. (Cited as: “Targeted Killings”)

US Air Force (2012). The Military Commander and the Law. (Cited as: Military Commander)

United Nations (2014). UN Launches Unmanned Surveillance Aircraft to Better Protect Civilians in Vast DRCongo. http://www.un.org/apps/news/story.asp?NewsID=46650\&Cr=democratic\&Cr1=congo\#.UxHwFoW3vs4

UPI (2014). Israel’s Defence Industry Boosts UAV Sales, Eyes Un-Manned Subs. http://www.upi.com/Business_News/Security-Industry/2014/02/03/Israels-defense-industry-boosts-UAV-sales-eyes-unma nned-subs/UPI-71741391461544/\#ixzz2sP73

Vogel, R. J. (2011). Drone Warfare and the Law of Armed Conflict. Denver Journal of International Law and Policy, 39, 101. 
Scientific Research Publishing (SCIRP) is one of the largest Open Access journal publishers. It is currently publishing more than 200 open access, online, peer-reviewed journals covering a wide range of academic disciplines. SCIRP serves the worldwide academic communities and contributes to the progress and application of science with its publication.

Other selected journals from SCIRP are listed as below. Submit your manuscript to us via either submit@scirp.org or Online Submission Portal.
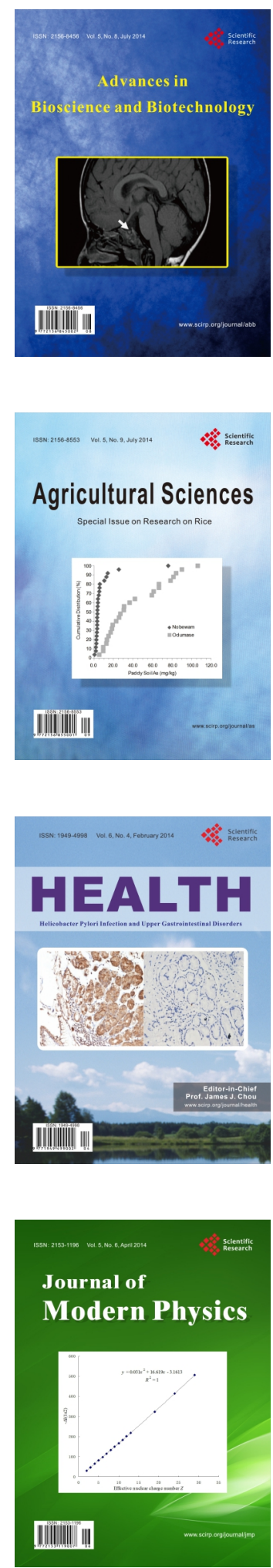
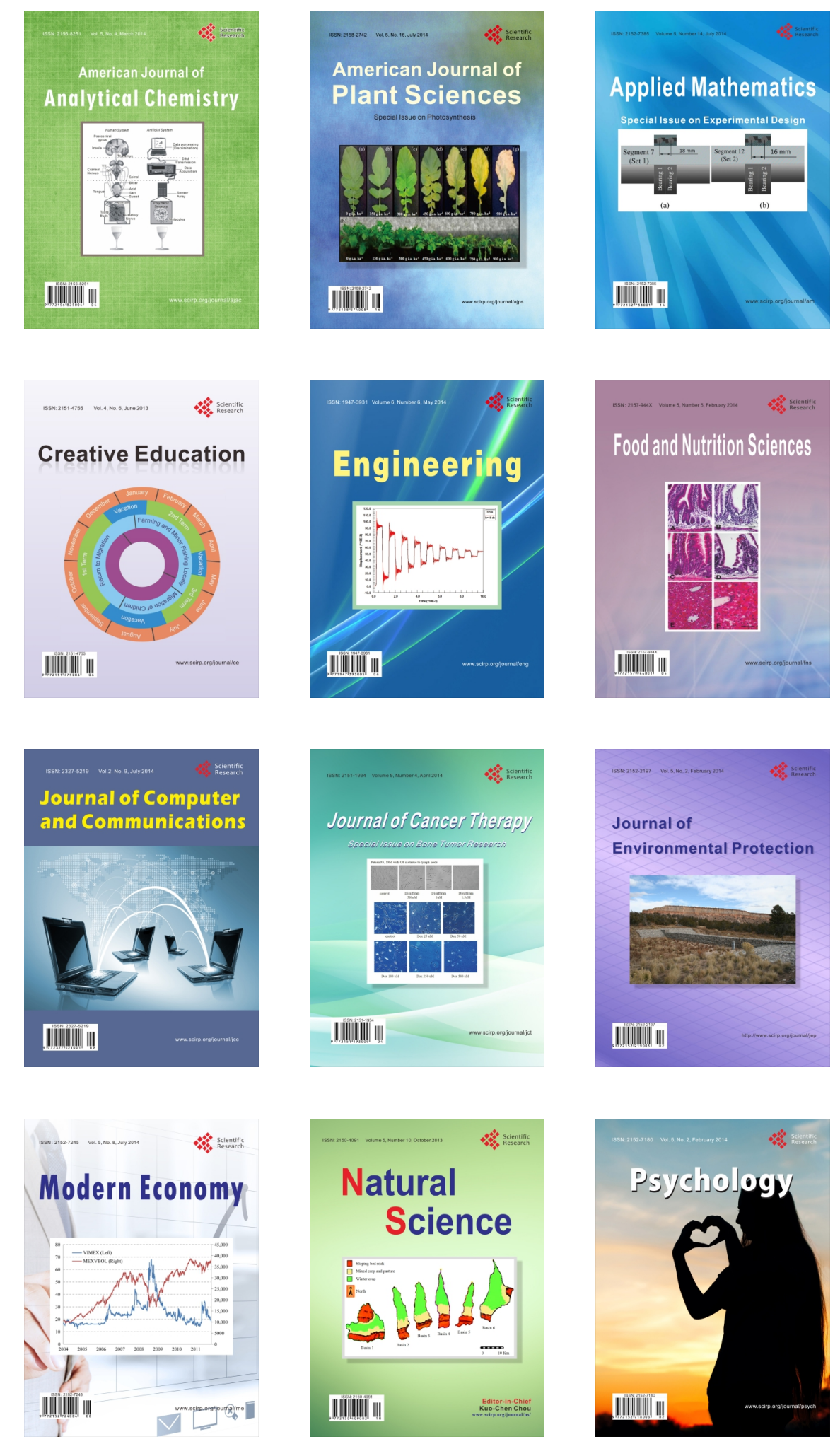